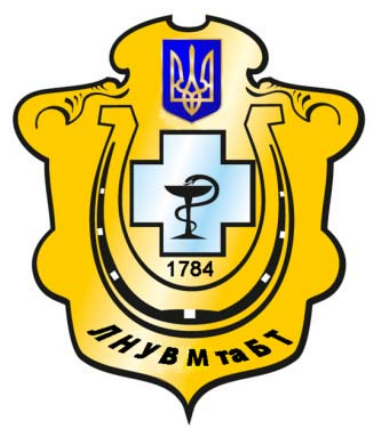

Науковий вісник Львівського національного університету ветеринарної медицини та біотехнологій імені С.З. Гжицького

Scientific Messenger of Lviv National University of Veterinary Medicine and Biotechnologies named after S.Z. Gzhytskyj

doi:10.15421/nvlvet7313

ISSN 2518-7554 print

ISSN 2518-1327 online

$\underline{\text { http://nvlvet.com.ua/ }}$

УДК 619:614.9.35

\title{
Бактерицидні та дезінфікуючі властивості деззасобу «Алкісепт-100»
}

\author{
О.Л. Тішин, Г.Т. Копійчук, Р.В. Хом’як, О.В. Хирівський, М.М. Данко \\ oleksandr.tishyn@gmail.com
}

\begin{abstract}
Державний науково-дослідний контрольний інститут ветеринарних препаратів та кормових добавок вул. Донецька, 11, м. Львів, 79019, Україна
\end{abstract}

\begin{abstract}
У статті наведені результати досліджень бактерицидних властивостей нового вітчизняного дезінфікуючого засобу «Алкісепт-100», створеного на основі глутарового альдегіду, дидецилдиметиламонію хлориду, алкілдиметилбензиламонію хлориду, гліоксалю та амінотриметиленфосфонової кислоти. Встановлено його бактерицидне розведення (БР), бактерииидну кониентрацію (БК), фенольний коефічієнт (ФК) та білковий індекс (БІ). Так, найбільш чутливими на дію деззасобу виявилися бактерії тест-культури Р. vulgaris, де загибель клітин наставала за 10 та 30 хвилинних експозиціях у концентраціях 0,26 та 0,18\%, відповідно. При дії деззасобу на грампозитивні мікроорганізми S. аитеия, вегетативні форми B. subtilis та на тест-культури S. typhimurium загибель клітин наставала за даних умов у концентраціях 0,72 i 0,52\%, відповідно. Грамнегативні мікроорганізми E. соІі виявились більш чутливими до дезінфектанта $і$ загибель клітин наставала за цих експозицій у кониентраціях 0,52 і 0,37\%, відповідно. БР даного деззасобу у 1,96 і 1,4 разів більше для E. coIi та $S$. аитеиs, відповідно, від БР фенолу, а в присутності білка активність досліджуваного деззасобу знижується в 2,74 рази. Визначена ефективність деззасобу щуодо штамів мікроорганізмів при знезараженні поверхонь тест-об'єктів. Встановлено, щяо для тест-культур E. coli ma S. aureus (без органічних домішок) 0,1\% концентрачія деззасобу малоефективна. Для споровоі форми B. subtilis малоефективна 4,0\% концентрація деззасобу. Він у 1,0-1,5\% концентраціях $i$ вище є ефективним для обробки поверхонь із дерева, металу та кахелю, які забруднені органічними речовинами, та об'єктів, які підлягають ветеринарному контролю, а при спорових формах мікроорганізмів його робоча концентрачія повинна бути 5,0\% $i$ вище, при експозиції у 120 хвилин і більше. Доведено, щзо дезінфікуючий засіб «Алкісепт-100» у виробничих умовах у концентраuіï 1,0\% за препаратом, иляхом вологого зрочення поверхні приміщення для утримання тварин та витрат робочого роз-

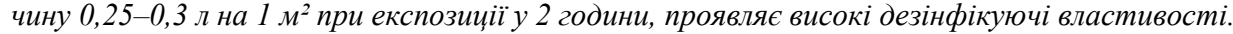

Ключові слова: деззасіб «Алкісепт-100», тест-культури, бактерицидне розведення, бактерицидна концентрація, фенольний коефіцієнт, білковий індекс, тест-об 'єкти, дезінфекція.
\end{abstract}

\section{Бактерицидные и дезинфицирующие свойства дезсредства «Алкисепт-100»}

\author{
А.Л. Тишин, Г.Т. Копийчук, Р.В. Хомяк, А.В. Хыривский, Н.Н. Данко \\ oleksandr.tishyn@gmail.com
}

\begin{abstract}
Государственный научно-исследовательский контрольный институт ветеринарных препаратов и кормовых добавок, ул. Донецкая, 11, г. Львов, 79019, Украина
\end{abstract}

В статье приведены результаты исследований бактерищидных свойств нового отечественного дезинфицирующего средства «Алкисепт-100», созданного на основе глутарового альдегида, дидецилдиметиламонию хлорида, алкилдиметилбензиламонию хлорида, глиоксаля и аминотриметиленфосфоновой кислоты. Установлено его бактерицидное разведение (БР), бактерицидную концентрацию (БК), фенольный коэффициент (ФК) и белковый индекс (БИ). Так, наиболее чувствительными на действие дезсредства оказались бактерии тест-культуры P. vulgaris, где гибель клеток наступала при 10 и 30 минутных экспозиция в концентрачиях 0,26 и 0,18\%, соответственно. При действии дезсредства на грамположительные микроорганизмы S. aureus, вегетативные формы B. subtilis и на тест-культуры S. tyрhітигіит гибель клеток наступала при данных условиях в конщентрациях 0,72 и 0,52\%, соответственно. Грамотрицательные микроорганизмы

\section{Citation:}

Tishyn, O.L., Kopijchuk, G.T., Khomiak, R.V., Khyrivskyy, O.V., Danko, M.M. (2017). Bactericidal and disinfective properties of disinfectant «Alkisept-100». Scientific Messenger LNUVMBT named after S.Z. Gzhytskyj, 19(73), 61-65. 
E. coli оказались более чувствительными к дезинфектанту и гибель клеток наступала в этих экспозиций в кониентрациях 0,52 и 0,37\%, соответственно. БР данного дезсредства в 1,96 и 1,4 раз больше для E. coli и S. аигеиs, соответственно, от БР фенола, а в присутствии белка активность исследуемого дезсредства снижается в 2,74 раза. Определена эффективность дезсредства по отночению к итаммам микроорганизмов при обеззараживании поверхностей тест-объектов. Установлено, что для тест культур E. coli u S. aureus (без органических примесей) 0,1\% концентрация дезсредства малоэффективна. Для споровой формы B. subtilis малоэффективна 4,0\% концентрация дезсредства. Оно в 1,01,5\% концентрациях и выше является эффективным для обработки поверхностей из дерева, металла и плитки, загрязненных органическими веществами, и объектов, подлежащих ветеринарному контролю, а при споровых формах микроорганизмов его рабочая концентрация должна быть 5,0\% и выше, при экспозиции в 120 минут и более. Доказано, что дезинфициирующее средство «Алкисепт-100» в производственных условиях в концентрации 1,0\% по препарату, путем влажного орошения поверхности помещчения для содержания животных и затрат рабочего раствора 0,25-0,3 л на 1 м² при экспозиции в 2 часа, проявляет высокие дезинфицирующие свойства.

Ключевые слова: дезсредство «Алкисепт-100», тест-культуры, бактерицидное разведение, бактерицидная концентрация, фенольный коэффициент, белковый индекс, тест-объекты, дезинфекция.

\title{
Bactericidal and disinfective properties of disinfectant «Alkisept-100»
}

\author{
O.L. Tishyn, G.T. Kopijchuk, R.V. Khomiak, O.V. Khyrivskyy, M.M. Danko \\ oleksandr.tishyn@gmail.com
}

\author{
State Scientific-Research Control Institute of Veterinary Medicinal Products and Feed Additives, \\ Donetska Str., 11, Lviv, 79019, Ukraine
}

The results of research bactericidal properties of new domestic disinfectant "Alkisept-100» that based on a glutaraldehyde, didecyldimethylammonium chloride, alkyldimethylbenzylammonium chloride and aminotrismethylenephosphonic acid. Was found bactericidal dilution (BD), bactericidal concentration (BC), phenol coefficient (FC) and protein index (PI). Most susceptible to the effect of disinfectant was test-cultures of P. vulgaris, where cell death came on the 10 and 30 minutes exposures at concentrations of 0.26 and $0.18 \%$, respectively. The action of disinfection preparation for gram-positive bacteria S. aureus, vegetative cells of B. subtilis vegetative cells and cultures of S.typhimurium test-cell death drew under these conditions at concentrations of 0.72 and $0.52 \%$, respectively. Gram-negative bacteria E. coli were more susceptible to disinfectant and cell death drew for these exposures at concentrations of 0.52 and $0.37 \%$, respectively. BD of this disinfectat were 1.96 and 1.4 higher times for E. coli and $S$. aureus, respectively, from BD phenol, and in the presence of protein activity investigated disinfection preparation is reduced to 2.74 times. The efficacy of disinfection preparation of microorganisms on surfaces in the decontamination of test objects. It is established that test cultures of E. coli and S. aureus (without organic impurities) at $0.1 \%$ concentration of disinfectant is ineffective. For spore form of B. subtilis disinfection preparation concentration at $4.0 \%$. Is ineffective At the $1.0-1.5 \%$ and higher concentrations is effective for surface treatment of wood, metal and tile that are contaminated with organic substances and objects subject to veterinary controls, and for elimination spore forms of microorganisms at its working concentration of desinfectant should be $5.0 \%$ or higher, the exposure in 120 minutes or more. Proved that the disinfectant «Alkisept-100» in a production environment at a concentration of $1.0 \%$ by wet surface irrigation facilities for animals and working solution 0.25-0.3 liters per 1 square meter with an exposure of 2 hours, showing high disinfectant properties.

Key words: disinfectant «Alkisept-100», test-culture, bactericidal dilution, bactericidal concentration, phenol coefficient, protein index, test objects, disinfection.

\section{Вступ}

Дезінфекція об'єктів утримання сільськогосподарських тварин, переробки продуктів тваринництва та їх реалізації є одним із основних заходів у системі профілактики та ліквідації інфекційних захворювань, забезпечення стійкого благополуччя тваринництва та високої санітарної якості харчових продуктів.

Ринок дезінфікуючих засобів України на сьогодні представлений їх широким асортиментом, більшість 3 яких у своєму складі містять одну чи декілька діючих речовин. Однак більшість 3 них не в повній мірі відповідають сучасним вимогам по універсальності, розчинності у воді, активності стосовно широкого спектру мікроорганізмів, неагресивності відносно різноманітних будівельних конструкцій і матеріалів, екологічної безпеки, оптимальному співвідношенню - «ефективність - витратна норма - ціна». Тому при дезінфекції об'єктів, що підлягають ветеринарно-санітарному нагляду доводиться переглядати існуючі режими дезін- фекції та використовувати нові, більш ефективні засоби (Serhiienko et al., 2010; Kotsiumbas et al., 2012).

Для вивчення бактерицидної активності та визначення ефективності різних концентрацій, представлено новий дезінфікуючий засіб «Алкісепт-100», для дезінфекції об'єктів, що підлягають ветеринарносанітарному нагляду. Дезінфектант являє собою прозорий світло-жовтого кольору, без механічних включень розчин, зі специфічним запахом. Добре змішується 3 водою. У 1000 мл деззасобу містяться такі діючі речовини: глутаровий альдегід - 157 г, дидецилдиметиламонію хлорид - 80 г, алкілдиметилбензиламонію хлорид - 125 г, гліоксаль - 100 г та амінотриметиленфосфонова кислота (АТМП) - 25 г.

Альдегідам притаманна сильна бактерицидна, туберкулоцидна, віруліцидна, фунгіцидна та спороцидна дія. 3 групи альдегідів для дезінфекції використовують гліоксалевий (гліоксаль) та глутаровий діальдегід. Їх активність зумовлена алкілюванням меркапто-, гідроксі-, карбоксі- й аміногруп РНК і ДНК та білків мікробів, що призводить до пригнічення синтезу біл- 
ків і нездатності до розмноження, а в результаті - до загибелі мікроорганізму. Гліоксаль - органічна сполука, жовта рідина та э найпростішим діальдегідом. Гліоксалевий альдегід у водних розчинах перебуває у гідролізованому стані й у газову фазу не переходить. Глутаровий альденід є основною діючою речовиною багатьох закордонних і вітчизняних препаратів для дезінфекції. Засоби на основі діальдегідів виявляють активність за наявності органічних речовин, не мають корозійної дії, не псують виробів з гуми, дерева і пластмаси (Vershniak, 2010; Prokudina, 2014).

Деззасоби на основі четвертинних амонієвих сполук (ЧАС) характеризуються хорошою розчинністю та мийним ефектом, антикорозійними й антистатичними властивостями. Серед ЧАС найуживаніші алкілдиметилбензиламонію хлорид і дидецилметиламонію хлорид. Ці сполуки входять до складу більшості сучасних найпоширеніших дезінфектантів та антисептиків і становлять основу більшої частини нових сучасних розробок як вітчизняного, так і закордонного виробництва. Їх дія полягає у здатності проникати в цитоплазматичну мембрану мікроорганізмів, що супроводжується незворотними змінами властивостей і структури нейтральних та кислих мембранних ліпідів, що призводить до підвищення проникності цитоплазматичної мембрани, витоку назовні цитоплазматичних компонентів 3 клітини, зниження активності ферментних систем. Підвищення концентрації ЧАС спричинює вимивання мембранних ліпідів і руйнування цитоплазматичної мембрани. Ефективніше, краще ніж деякі окиснювачі з хлором і йодом, руйнують ДНК-вмістимі оболонкові віруси (Kotsiumbas et al., 2006; Vershniak, 2010; Prokudina, 2014).

АТМП - амінотриметиленфосфонова кислота навіть при малих концентраціях гальмує утворення кристалів карбонату кальцію і таким чином запобігає утворенню накипу. Завдяки цим властивостям вона запобігає утворенню відкладень, здійснює інгібування корозії, видаляє накип і продукти корозії.

Знезаражуючий ефект розчинів деззасобу «Алкісепт-100» грунтується на їх широкому спектрі антимікробної дії по відношенню до різних грамнегативних та грампозитивних мікроорганізмів, при інфекціях бактеріальної, вірусної та грибкової етіології. Він призначений для вологої та аерозольної дезінфекції, деконтамінації об'єктів, що підлягають ветеринарносанітарному нагляду. Термін зберігання засобу 2 роки $з$ дня виготовлення.

Метою роботи було вивчення бактерицидної активності, визначення ефективності різних концентрацій деззасобу «Алкісепт-100» при дезінфекції об'єктів, що підлягають ветеринарному нагляду, та встановлення при його застосуванні режимів дезінфекції.

\section{Матеріал і методи досліджень}

Бактерицидне розведення (БР) i бактерицидну концентрацію (БК) дезінфікуючого засобу «Алкісепт100» визначали in vitro на штамах культур Escherichia coli (1257), Staphylococcus aureus (209), Salmonella typhimurium, Bacilus subtilis (вегетативна форма), Proteus vulgaris. Для вивчення бактерицидних властивостей робили серійні розведення та визначали ефективність розведення деззасобу, в яких було відмічено загибель тест-культур, та наявність їх росту в контролі.

При вивченні фенольного коефіцієнту (ФК) визначали БР фенолу і досліджуваного деззасобу до кишкової палички та золотистого стафілококу.

Для вивчення білкового індексу (БІ), який робили на культурі E. coli, показник БР досліджуваного деззасобу при відсутності білка порівнювали 3 показником БР у досліді з білком.

Вивчення антимікробної активності деззасобу «Алкісепт-100» при знезараженні поверхонь тестоб'єктів, контамінованих музейними штамами культур E. coli, S. aureus, B. subtilis (вегетативна та спорова форми) 3 незабрудненням та забрудненням органічними речовинами, 3 метою розроблення режиму знезараження їх в залежності від концентрації розчину, кратності обробки, витрати на $1 \mathrm{~m}^{2}$ поверхні та експозиції, проводили на пластинках із дерева, заліза та кахелю $з$ нанесенням на них суміші тесткультур із розрахунку 1 мл двохміліардної суміші на 1 тест-об'єкт.

Бактеріологічний контроль якості дезінфекції приміщень для утримання ВРX проводили у ФГ «Лелик» (смт. Куликів Жовківського району Львівської області) деззасобом «Алкісепт-100» у 1\% концентрації за препаратом, шляхом вологого зрошення поверхні приміщення та його витрат -250 300 мл на 1 м $^{2}$ за експозиції у 120 хвилин.

Дослідження проводили згідно 3 методичними рекомендаціями «Методи визначення та оцінки показників безпеки і якості дезінфікуючих, мийнодезінфікуючих засобів, що застосовуються під час виробництва, зберігання, транспортування та реалізації продукції тваринного походження».

\section{Результати та їх обговорення}

При вивченні мінімальної БК дезінфікуючого засобу «Алкісепт-100» по відношенню до мікроорганізмів встановлено, що найбільш чутливими на дію деззасобу виявилися бактерії тест-культури P. vulgaris, де загибель клітин наставала за 10 та 30 хвилинних експозиціях у концентраціях 0,26 і 0,18\%, відповідно (табл. 1).

При дії деззасобу на грампозитивні мікроорганізми $S$. aureus, вегетативні форми B. subtilis та на тесткультури S. typhimurium загибель клітин наставала за 10 та 30 хвилинних експозиціях у концентраціях 0,72 і 0,52\%, відповідно. Грамнегативні мікроорганізми E. coli виявились більш чутливими до дезінфектанта і загибель клітин наставала за цих експозицій у концентраціях 0,52 і 0,37\%, відповідно (табл. 1).

При визаченні ФК встановлено, що БР деззасобу відносно тест-культур більше, порівняно з БР фенолу, i середній ФК становить 1,96 для E. coIi та 1,4 для S. aureus, тобто БР даного деззасобу у 1,96 і 1,4 разів більше до даних тест-культур, відповідно, від БР фенолу. Дані досліджень представлені у таблиці 2. 
При проведенні досліджень встановлено, що в присутності білка активність досліджуваного деззасобу знижується в 2,74 рази (табл. 3 ).

При визначенні ефективності знезаражуючих властивостей дезінфікуючого засобу на тест-об'єктах встановлено, що для тест-культур E. coli та S. aureus (без органічних домішок) $0,1 \%$ концентрація деззасобу малоефективна. Для спорової форми B. subtilis малоефективна 4,0\% концентрація деззасобу (табл. 4).
Одержані результати свідчать, що деззасіб у 0,3\% концентрації для асептичного прибирання: гладких поверхонь 3 кахелю, синтетичних матеріалів, лабораторних приміщень ветеринарних клінік, тарних засобів транспортування продукції тваринного походження, замочування спецодягу перед його пранням можливий при експозиції у 60 хвилин і більше (табл. 4).

Таблиия 1

Бактерицидне розведення та бактерицидна концентрація деззасобу «Алкісепт-100» до тест-культур

\begin{tabular}{|c|c|c|c|}
\hline Культура & Експозиція, хвилин & БР & БК, \% \\
\hline \multirow{2}{*}{ E. coli } & 10 & $1: 192,1$ & 0,52 \\
\hline \multirow{2}{*}{ S. aureus } & 30 & $1: 268,9$ & 0,37 \\
\hline \multirow{2}{*}{ S. typhimurium } & 10 & $1: 137,2$ & 0,72 \\
\hline \multirow{2}{*}{ P. vulgaris } & 30 & $1: 192,1$ & 0,52 \\
\hline B. subtilis & 10 & $1: 137,2$ & 0,72 \\
(вегетативна форма) & 30 & $1: 376,5$ & 0,26 \\
\hline
\end{tabular}

Примітка: БР - бактерицидне розведення; БК - бактерицидна концентрація

Фенольний коефіціснт деззасобу «Алкісепт-100» до тест-культур E. coli та S. aureus

Табличяя 2

\begin{tabular}{|c|c|c|c|c|c|}
\hline Тест-культури & $\begin{array}{c}\text { Експозиція, } \\
\text { хвилин }\end{array}$ & $\begin{array}{c}\text { Бактерицидне } \\
\text { розведення } \\
\text { деззасобу } \\
\end{array}$ & $\begin{array}{c}\text { Бактерицидне } \\
\text { розведення фенолу }\end{array}$ & $\begin{array}{l}\text { Фенольний } \\
\text { коефіцієнт }\end{array}$ & $\begin{array}{c}\text { Середній феноль- } \\
\text { ний коефіцієнт }\end{array}$ \\
\hline E. coli & $\begin{array}{l}10 \\
30 \\
\end{array}$ & $\begin{array}{l}1: 192,1 \\
1: 268,9 \\
\end{array}$ & $\begin{array}{c}1: 98 \\
1: 137,2 \\
\end{array}$ & $\begin{array}{l}1,96 \\
1,96 \\
\end{array}$ & 1,96 \\
\hline S. aureus & $\begin{array}{l}10 \\
30\end{array}$ & $\begin{array}{l}1: 137,2, \\
1: 192,1\end{array}$ & $\begin{array}{c}1: 98 \\
1: 137,2\end{array}$ & $\begin{array}{l}1,4 \\
1,4\end{array}$ & 1,4 \\
\hline
\end{tabular}

Білковий індекс деззасобу «Алкісепт-100»

\begin{tabular}{|c|c|c|c|c|}
\hline \multirow{2}{*}{ Культура } & $\begin{array}{c}\text { Бакрозведення } \\
\text { без білка }\end{array}$ & $\begin{array}{c}\text { Бакрозведення } \\
\text { 3 білком }\end{array}$ & $\begin{array}{c}\text { Білковий } \\
\text { індекс }\end{array}$ & $\begin{array}{c}\text { Середній } \\
\text { білковий індекс }\end{array}$ \\
\hline \multirow{2}{*}{ E. coli } & 10 хв. $-1: 192,1$ & 10 хв. $-1: 70$ & 2,74 & 2,74 \\
\hline
\end{tabular}

Дезінфікуючі властивості «Алкісепт-100» на тест-об’єктах

Таблиияя 4 з культурами E. coli, S. aureus та B. subtilis (вегетативна та спорова форми)

\begin{tabular}{|c|c|c|c|c|c|c|c|c|c|}
\hline \multirow{3}{*}{ Концентрація } & \multicolumn{3}{|c|}{ Дерево } & \multicolumn{3}{|c|}{ Кахель } & \multicolumn{3}{|c|}{ Залізо } \\
\hline & \multicolumn{9}{|c|}{ Експозиція, хвилин } \\
\hline & 30 & 60 & 120 & 30 & 60 & 120 & 30 & 60 & 120 \\
\hline $0,1 \%$ (E. coli та $S$. aureus $)$ & + & + & + & + & + & + & + & + & + \\
\hline $0,3 \%$ (E. coli та $S$. aureus) & + & - & - & + & - & - & + & - & - \\
\hline $0,5 \%$ (E. coli та $S$. aureus) & - & - & - & - & - & - & - & - & - \\
\hline $1,0 \%$ (E. coli та $S$. aureus) & - & - & - & - & - & - & - & - & - \\
\hline $\begin{array}{c}1,0 \% \text { (E. coli та } S . \text { aureus) } \\
\text { з забрудненням органічними речовинами }\end{array}$ & + & - & - & + & - & - & + & - & - \\
\hline $\begin{array}{c}1,5 \% \text { (E. coli та } S . \text { aureus) } \\
\text { з забрудненням органічними речовинами }\end{array}$ & - & - & - & - & - & - & - & - & - \\
\hline $\begin{array}{c}\text { 3,0\% B. subtilis (вегетативна форма) } \\
\text { з забрудненням органічними речовинами }\end{array}$ & + & - & - & + & - & - & + & - & - \\
\hline $\begin{array}{c}\text { 4,0\% B. subtilis (вегетативна форма) } \\
\text { з забрудненням органічними речовинами }\end{array}$ & - & - & - & - & - & - & - & - & - \\
\hline $\begin{array}{c}4,0 \% \text { B. subtilis (спорова форма) } \\
\text { з забрудненням органічними речовинами }\end{array}$ & + & + & - & + & - & - & - & - & - \\
\hline $\begin{array}{c}5,0 \% \text { B. subtilis (спорова форма) } \\
\text { з забрудненням органічними речовинами }\end{array}$ & - & - & - & - & - & - & - & - & - \\
\hline
\end{tabular}


Обеззаражуючі 1,0-1,5\% концентрації деззасобу для санації жорстких поверхонь, при профілактичній дезінфекції приміщень для тварин та птиці, які забруднені органічними речовинами, достатні при експозиції у 60 хвилин і більше.

При дезінфекції об'єктів, які підлягають ветеринарному контролю, при спорових формах мікроорганізмів робоча концентрація дезрозчину повинна бути 5,0\% і вище, при експозиції у 60-120 хвилин і більше (табл. 4).

Під час профілактичної дезінфекції приміщення для утримання великої рогатої худоби у фермерському господарстві «Лелик» смт. Куликів Жовківського району Львівської області деззасобом «Алкісепт-100» у концентрації 1,0\% за препаратом, шляхом вологого зрошення поверхні приміщення та витрат робочого розчину $0,25-0,3$ л на $1 \mathrm{~m}^{2}$ при експозиції у 2 години, згідно методичних рекомендацій проведені дослідження 3 визначення якості дезінфекції. 3 поверхонь приміщень, які піддавалися дезінфекції, тест-мікробів кишкової палички та стафілококу не було виділено. Дезінфекція приміщення (для ВРХ), яка проведена $1,0 \%$ водним розчином «Алкісепт-100» за 120хвилинної експозиції - якісна.

\section{Висновки}

Знезаражуюча бактерицидна концентрацій деззасобу «Алкісепт-100» за експозиції 10 та 30 хвилин становить відносно S. aureus, S. typhimurium та B. subtilis (вегетативна форма) 0,72 і 0,52\%, E. coli 0,52 i $0,37 \%$, B. subtilis - 1,43 і $0,73 \%$ та P. vulgaris 0,26 і 0,18\%, відповідно.

Бактерицидна дія даного деззасобу відносно тесткультур E. coI $i$ та S. aureus у 1,96 і 1,4 разів, відповідно, більша від фенолу.

В присутності білка активність досліджуваного деззасобу знижується в 2,74 рази.

Деззасіб «Алкісепт-100» $є$ ефективним при дезінфекції об'єктів, які підлягають ветнагляду за концентраціях 1,0-1,5\% при умові експозиції від
120 хвилин та за концентрації 5\% для спорових форм мікроорганізмів.

Перспективи подальших досліджень. Дослідження дезінфікуючого засобу на токсичність.

\section{Бібліографічні посилання}

Kotsiumbas, I.Ia., Tishyn, O.L., Khom'iak, R.V. (2012). Bakteriolohichni vlastyvysti dezinfikuiuchoho zasobu Aerosan. Naukovo-tekhnichnyi biuleten Instytutu biolohii tvaryn ta DNDKI vetpreparativ ta kormovykh dobavok. 13(3-4), 21-214 (in Ukrainian).

Serhiienko, O.I., Kovalchyk, L.M., Velychko, V.O. (2010). Preparaty serii Krystal - efektyvni dezinfektsiini zasoby profilaktyky ta likvidatsii infektsiinykh i invaziinykh zakhvoriuvan. Naukovyi visnyk LNUVMBT imeni S. Z. Hzhytskoho. 12, 2(44), 279-282 (in Ukrainian).

Prokudina, N. (2014). Dezinfektant krashche vybyraty vysokoaktyvnyi, bahatofunktsionalnyi, z prolonhovanoiu diieiu, bezpechnyi dlia liudyny i ptytsi. Nashe ptakhivnytstvo. 11, 12-16 (in Ukrainian).

Vershniak, T.V. (2010). Dezinfektanty. Ahrobiznes sohodni. 13(188), 33-36 (in Ukrainian).

Kotsiumbas, I.Ia., Serhiienko, O.I., Kovalchyk, L.M. (2006). «Krystal-1000»- universalnyi dezinfektsiinyi zasib novoho pokolinnia. Visnyk Bilotserkivskoho ahrarnoho universytetu. 39, 95-100 (in Ukrainian).

Metody vyznachennia ta otsinky pokaznykiv bezpeky i yakosti dezinfikuiuchykh, myino-dezinfikuiuchykh zasobiv, shcho zastosovuiutsia pid chas vyrobnytstva, zberihannia, transportuvannia ta realizatsii produktsii tvarynnoho pokhodzhennia (Metodychni rekomendatsii), zatverdzheni Derzhkomitetom vetmedytsyny Ukrainy protokol № 1 vid 23.12.2009 roku. Veterynarna dezinfektsiia (Instruktsiia ta metodychni rekomendatsii). - Kyiv, 2010, 65-152 (in Ukrainian).

Стаття надійшла до редакиії 22.03.2017 